\title{
AN EVOLUTIONARY PERSPECTIVE ON ADIPONECTIN AND INSULIN GENE PROMOTERS
}

\author{
Paul Gagniuc ${ }^{1}$ and Constantin lonescu-Tirgovişte ${ }^{2}$ \\ 'Institute of Genetics, University of Bucharest, and ${ }^{2}$ National Institute of Diabetes, Nutrition and Metabolic Diseases \\ "N.C. Paulescu", Bucharest, Romania
}

\begin{abstract}
Insulin, discovered in 1921 by Nicolae Paulescu, and adiponectin, discovered in 1995 by Yuji Matsuzawa's and two other groups, are two important molecules related to the maintenance of human energy homeostasis. The close relationship of these two hormones in the development of metabolic pathology (obesity, metabolic syndrome, type 2 diabetes mellitus) prompted us to use a bioinformatic approach in order to better understand the architecture of their gene promoters. In this study, a comprehensive analysis was undertaken for adiponectin (ADIPOQ) and insulin (INS) gene promoter sequences from 7 species. In our approach we used 14 promoter sequences $(7$ promoters for each gene) from HomoloGene (NCBI). In order to examine the structural particularities of ADIPOQ and INS gene promoters, we used two-dimensional image-based patterns obtained through Kappa Index of Coincidence (Kappa IC) and $(C+G) \%$ values. We observed that $C+G$ content variations of ADIPOQ promoter correlates with body mass, whereas high Kappa IC values of the INS gene promoter appear to be correlated with brain size.
\end{abstract}

Adipobiology 2012; 4: 111-115

Key words: ADIPOQ gene promoter, INS gene promoter, body mass, brain mass, BMI, evolution

Received 5 September 2012, revised 12 September 2012, accepted 14 September 2012.

Correspondence and reprint request to Dr Paul Gagniuc, E-mail: paul_gagniuc@acad.ro and Prof. Constantin lonescu-Tirgovişte, E-mail: cit@paulescu.ro

\section{Introduction}

In our society, obesity is a direct consequence of lifestyle, environmental exposuers, and genetic predispostion (1-3). It is currently associated with a considerable number of pathological conditions, such as type 2 diabetes mellitus (T2DM), cardiovascular disease, arthritis and other various complications $(1,4)$.

Adipose tissue is the major „warehouse" for triglycerides and a main link in the energy balance mechanism. Generally, adipose tissue mass increases when energy intake exceeds energy consumption. Thus, the adipose tissue stands to be as an active and dynamic endocrine subsystem that produces a number of signaling proteins known as adipokines, which affect the function of adjacent and/ or distant organs in health and disease (5-8). Examples of "the rapidly expanding family of adipokines" (9) include adipsin, leptin, adiponectin, apelin, chemerin, interleukin-6 (IL-6), IL-10, plasminogen activator inhibitor-1 (PAI-1), retinol-binding protein 4 (RBP4), tumor necrosis factor-alpha (TNF- $\alpha$ ) and visfatin (8-10). The most 
abundant adipokine is adiponectin (a relatively large 244-amino-acid-long polypeptide) which is found in human serum at high concentrations (between $2-20 \mu \mathrm{g} / \mathrm{mL}$ ) and is inversely correlated with body mass index (BMI), T2DM, atherogensis and cancerogensis (11-15). In the bloodstream, adiponectin circulates in different forms, such as trimeric, hexameric and higher order complexes (16). Adiponectin treatment is able to counteract T2DM and atherosclerosis as well as other pathological states (17-25). Compared to normal individuals in which adiponectin is inversely related to glucose and insulin, the obese patients exhibit decreased concentrations of adiponectin $(26,27)$. We suggest that an overview from an evolutionary perspective of insulin and adiponectin may open new avenues for addressing the issues in both obesity and T2DM.

In the present study, we tried to observe two correlations in several species: $(i)$ between body mass (not to be confused with BMI) and ADIPOQ gene promoters, and (ii) between brain mass and INS gene promoters. In order to understand their cor- relation at the genetic level, we used our own original method based on Kappa index of coincidence, as previously published (28).

In our approach we used 14 promoter sequences (7 promoters for each gene) from HomoloGene (29). We used 500 bases upstream of ADIPOQ gene and INS gene from Homo sapiens (NT_005612.16), P. troglodytes (NW_003456895.1), C. lupus (NW_003726120.1), B. taurus (NW_003103812.1), M. musculus (NW_003103812.1), R. norvegicus (NW_047356.1) and G. gallus (NW_001471743.2). We used Visual Basic to develop a software program for promoter analysis - called PromKappa (Fig. 1). In this method we have used sliding window approach for reading two types of values: Kappa IC and $(\mathrm{C}+\mathrm{G}) \%$.

We observed that $\mathrm{C}+\mathrm{G}$ content variations of ADIPOQ promoter seem to be correlated with body mass. On the other hand, high Kappa IC values of INS gene promoter appear to be correlated with brain size. In this case, high Kappa IC values are caused by long $\mathrm{C}+\mathrm{G}$ based homopolymers. Thus the correlation

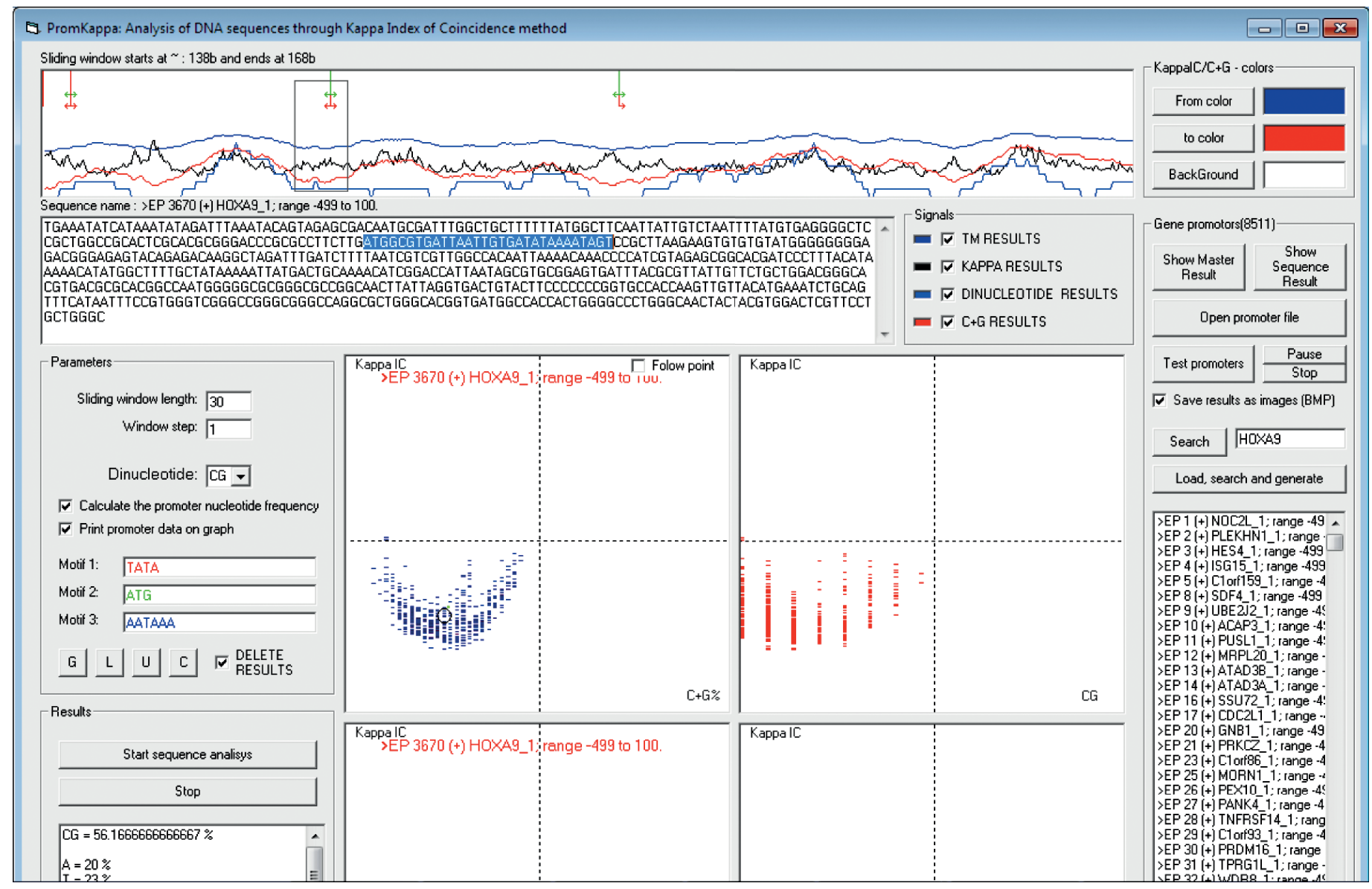

Figure 1. Prom Kappa Software (Promoter analysis by Kappa). 
is made between long $\mathrm{C}+\mathrm{G}$ based homopolymers and brain size (Fig. 2). Moreover, from a genetic point of view, one of the genome areas associated with susceptibility for T2DM includes adiponectin $(30,31)$. Several missense mutations of adiponectin are also associated with T2DM $(32,33)$. Clinically, adiponectin serum levels are reduced in obese or T2DM patients and are especially low in obese individuals with high visceral fat content (34-36). Furthermore, it was observed that anti-diabetic drugs cause an increase in adiponectin levels (37). Adiponectin receptors (Adip-R1 and Adip-R2) were found to be expressed in the proopiomelanocortin and neuropeptide tyrosine (NPY) neurons in the arcuate nucleus, thus, linking adiponectin to an even more active role in the central regulation of energy intake and consumption (38).

Interestingly, some studies suggest that T2DM in octogenarians is associated with decreased low molecular weight of adiponectin (39). Adiponectin molecules self-associate into larger structures. In this process of self-association, three adiponectin molecules bind together to form a trimer, units that continue to self-associate in hexamers or dodecamers (40). In human serum, the relative levels of adiponectin higher-order structures (high-molecular weight forms) seem to be increased in females. In relation to glucose homeostasis, the high-molecular weight form of adiponectin appears to be more biologically active and was associated with a lower risk of T2DM $(41,42)$.

Other studies link obesity (through low adiponectin levels) to an elevated risk of breast, colorectal or prostate cancer (4346). Also, adiponectin can reduce cell migration and invasion in cancer (47). Nevertheless, the biochemical mechanisms behind the action of adiponectin in cancer prevention are unknown. Although the beneficial implications of adiponectin start getting increasingly clearer, the clinical trials regarding an adiponectin therapy in humans has yet to be expected. The administration of adiponectin in mouse has already shown promising effects (48-50).

Figure 2. Promoter patterns of ADIPOQ and INS gene promoters. Each promoter pattern is composed of vertically aligned clusters of Kappa IC ( $y$-axis) and GC\% (x-axis) values. The center of weight for each pattern is represented by a black circle. Both values have a range between 1 and 100 .

\section{INS ADIPOQ}
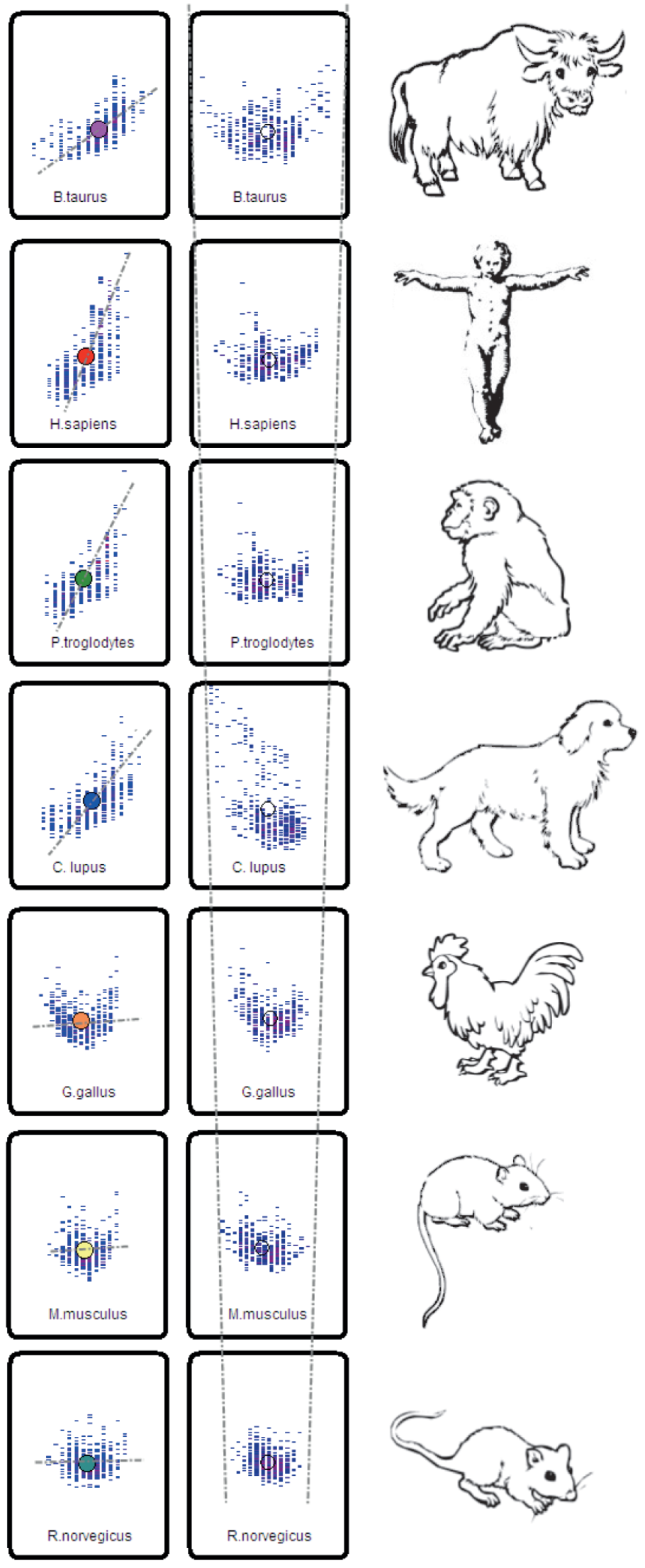
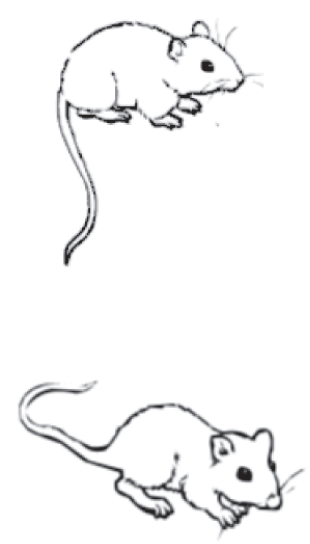


\section{Conclusion}

The role of adiponectin in developing T2DM prompted many studies over the last 10 years. In this paper, a comprehensive analysis was undertaken for ADIPOQ and INS promoter sequences from 7 species. In our approach we used 14 promoter sequences (7 promoters for each gene) from HomoloGene (NCBI). In order to examine the structural particularities of ADIPOQ and INS gene promoters, we used two-dimensional image-based patterns obtained through Kappa Index of Coincidence (Kappa IC) and $(\mathrm{C}+\mathrm{G}) \%$ values. In our analysis we observed that $\mathrm{C}+\mathrm{G}$ content variations of ADIPOQ promoter correlates with body mass. On the other hand, high Kappa IC values of INS gene promoter appear to be correlated with brain size. Our data also suggests that $\mathrm{C}+\mathrm{G}$ content variations of ADIPOQ promoter correlates with body mass. How interaction between insulin and adiponectin could explain the actual cardiometabolic pathologies remains to be Danced round using metabolomic, interactomic and genomic approaches.

\section{Acknowledgments}

This work was supported by a grant of the Romanian National Authority for Scientific Research, CNCS-UEFISCDI, project number PN-II-ID-PCE-2011-3-0429.

\section{References}

1. Kopelman PG. Obesity as a medical problem. Nature 2000; 404: 635-643.

2. Mokdad AH, Bowman BA, Ford ES, Vinicor F, Marks JS, Koplan JP. The continuing epidemics of obesity and diabetes in the United States. JAMA 2001;286: 1195-200.

3. Ionescu-Tirgoviste, C. Prolegomenon to the European Constitution Book of diabetes mellitus. Proc Rom Acad Series B 2008; 10: 179-213.

4. Ouchi N, Ohashi K, Shibata R, Murohara T. Adipocytokines and obesity-linked disorders. Nagoya J Med Sci 2012;74: 19-30.

5. Kershaw EE, Flier JS. Adipose tissue as an endocrine organ. J Clin Endocrinol Metab 2004;89: 2548-2556.

6. Mohamed-Ali V, Pinkney JH, Coppack SW. Adipose tissue as an endocrine and paracrine organ. Int J Obes Relat Metab Disord 1998;22: 1145-1158.

7. Havel PJ. Role of adipose tissue in body-weight regulation: mechanisms regulating leptin production and energy balance. Proc Nutr Soc 2000;59: 359-371.

8. Chaldakov GN, Stankulov IS, Hristova MG, Ghenev PI. Adipobiology of disease: adipokines and adipokine-targeted pharmacology. Curr Pharm Des 2003; 9: 1023-1031.

9. MacDougald OA, Burant CF. The rapidly expanding family of adipokines. Cell Metab 2007;6: 159-161.
10. Galic S, Oakhill JS, Steinberg GR. Adipose tissue as an endocrine organ. Mol Cell Endocrinol 2010;316: 129-139.

11. Grossmann ME, Nkhata KJ, Mizuno NK, Ray A, Cleary MP. Effects of adiponectin on breast cancer cell growth and signaling. Br J Cancer 2008; 98: 370-379.

12. Ryan AS, Berman DM, Nicklas BJ, Sinha M, Gingerich RL, Meneilly GS, et al. Plasma adiponectin and leptin levels, body composition, and glucose utilization in adult women with wide ranges of age and obesity. Diabetes Care 2003; 26: 2383-2388.

13. Chiarugi P, Fiaschi T. Adiponectin in health and diseases: from metabolic syndrome to tissue regeneration. Expert Opin Ther Targets 2010;14: 193-206.

14. Chen X, Wang Y. Adiponectin and breast cancer. Med Oncol 2011;28: 1288-1295.

15. Shibata R, Ouchi N, Murohara T. Adiponectin and cardiovascular disease. Circ J 2009;73: 608-614.

16. Fang X, Sweeney G. Mechanisms regulating energy metabolism by adiponectin in obesity and diabetes. Biochem Soc Trans 2006;34(Pt5): 798-801.

17. Nawrocki AR, Rajala MW, Tomas E, Pajvani UB, Saha AK, Trumbauer ME, et al. Mice lacking adiponectin show decreased hepatic insulin sensitivity and reduced responsiveness to peroxisome proliferatoractivated receptor gamma agonists. J Biol Chem 2006;281: 2654-2660.

18. Maeda N, Shimomura I, Kishida K, Nishizawa H, Matsuda $\mathrm{M}$, Nagaretani $\mathrm{H}$, et al. Diet-induced insulin resistance in mice lacking adiponectin/ACRP30. Nat Med 2002;8: 731-737.

19. Vasilescu R, Ifrim S, Ionescu-Tîrgovişte C. Leptin to adiponectin ratio is an independent predictor of common carotid artery intima-media thickness in obese subjects. Proc Rom Acad Series B 2010; 12: 209-217.

20. Birkenfeld AL, Boschmann M, Engeli S, Moro C, Arafat AM, Luft FC, et al. Atrial natriuretic peptide and adiponectin interactions in man. PLoS One 2012;7: e43238.

21. Barb D, Williams CJ, Neuwirth AK, Mantzoros CS. Adiponectin in relation to malignancies: a review of existing basic research and clinical evidence. Am J Clin Nutr 2007;86: s858-866.

22. Hu PF, Bao JP, Wu LD. The emerging role of adipokines in osteoarthritis: a narrative review. Mol Biol Rep 2010;38: 873-878.

23. Ziemke F, Mantzoros CS. Adiponectin in insulin resistance: lessons from translational research. Am J Clin Nutr 2010;91: 258S-261S.

24. Schaffler A, Scholmerich J, Buechler C. Mechanisms of disease: adipokines and breast cancer - endocrine and paracrine mechanisms that connect adiposity and breast cancer. Nat Clin Pract Endocrinol Metab 2007;3: 345-354. 
25. Yamauchi T, Kamon J, Waki H, Terauchi Y, Kubota N, Hara $\mathrm{K}$, et al. The fat-derived hormone adiponectin reverses insulin resistance associated with both lipoatrophy and obesity. Nat Med 2001;7: 941-946.

26. Kadowaki T, Yamauch T. Adiponectin and adiponectin receptors. Endocr Rev 2005; 26: 439-451.

27. Lihn AS, Pedersen SB, Richelsen B. Adiponectin: action, regulation and association to insulin sensitivity. Obes Rev 2005;6: 13-21.

28. Gagniuc P, Cristea PD, Tuduce R, Ionescu-Tîrgovişte C, Gavrila L. DNA patterns and evolutionary signatures obtained through Kappa Index of coincidence. Rev Roum Sci Techn - Électrotechn et Énerg 2012;57: 100-109.

29. Sayers EW, Barrett T, Benson DA, Bolton E, Bryant SH, Canese K, et al. Database resources of the National Center for Biotechnology Information. Nucleic Acids Res 2012;40: D13-25.

30. Mori Y, Otabe S, Dina C, Yasuda K, Populaire C, Lecoeur $\mathrm{C}$, et al. Genome-wide search for type 2 diabetes in Japanese affected sib-pairs confirms susceptibility genes on $3 q$, $15 \mathrm{q}$, and $20 \mathrm{q}$ and identifies two new candidate Loci on $7 \mathrm{p}$ and 11p. Diabetes 2002;51: 1247-1255.

31. Vionnet N, Hani EH, Dupont S, Gallina S, Francke S, Dotte $S$, et al. Genomewide search for type 2 diabetes-susceptibility genes in French whites: evidence for a novel susceptibility locus for early-onset diabetes on chromosome 3q27-qter and independent replication of a type 2-diabetes locus on chromosome 1q21-q24. Am J Hum Genet 2000;67: 1470-1480.

32. Hara K, Boutin P, Mori Y, Tobe K, Dina C, Yasuda K, et al. Genetic variation in the gene encoding adiponectin is associated with an increased risk of type 2 diabetes in the Japanese population. Diabetes 2002;51: 536-540.

33. Kondo H, Shimomura I, Matsukawa Y, Kumada M, Takahashi M, Matsuda M, et al. Association of adiponectin mutation with type 2 diabetes: a candidate gene for the insulin resistance syndrome. Diabetes 2002;51: 2325-2328.

34. Hotta K, Funahashi T, Arita Y, Takahashi M, Matsuda M, Okamoto Y, et al. Plasma concentrations of a novel, adipose-specific protein, adiponectin, in type 2 diabetic patients. Arterioscler Thromb Vasc Biol 2000;20: 1595-1599.

35. Weyer C, Funahashi T, Tanaka S, Hotta K, Matsuzawa Y, Pratley RE, et al. Hypoadiponectinemia in obesity and type 2 diabetes: close association with insulin resistance and hyperinsulinemia. J Clin Endocrinol Metab 2001;86: 19301935.

36. Brochu-Gaudreau K, Rehfeldt C, Blouin R, Bordignon V, Murphy BD, Palin MF. Adiponectin action from head to toe. Endocrine 2010; 37: 11-32.

37. Maeda N, Takahashi M, Funahashi T, Kihara S, Nishi- zawa $\mathrm{H}$, Kishida $\mathrm{K}$, et al. PPARgamma ligands increase expression and plasma concentrations of adiponectin, an adipose-derived protein. Diabetes 2001;50: 2094-2099.

38. Guillod-Maximin E, Roy AF, Vacher CM, Aubourg A, Bailleux V, Lorsignol A, et al. Adiponectin receptors are expressed in hypothalamus hypothalamus and colocalized with proopiomelanocortin and neuropeptide $\mathrm{Y}$ in rodent arcuate neurons. J Endocrinol 2009;200: 93-105.

39. Graessler J, Gruber M, Radke RB, Kopprasch S, Schwarz $\mathrm{PE}$, Kamke W, et al. Type 2 diabetes in octogenarians is associated with decreased low molecular weight adiponectin. Gerontology 2011;57: 316-326.

40. Briggs DB, Jones CM, Mashalidis EH, Nuñez M, Hausrath AC, Wysocki VH, et al. Disulfide-dependent self-assembly of adiponectin octadecamers from trimers and presence of stable octadecameric adiponectin lacking disulfide bonds in vitro. Biochemistry 2009;48: 12345-12357.

41. Oh DK, Ciaraldi T, Henry RR. Adiponectin in health and disease. Diabetes Obes Metab 2007;9: 282-289.

42. Zhu N, Pankow JS, Ballantyne CM, Couper D, Hoogeveen RC, Pereira M, et al. High-molecular-weight adiponectin and the risk of type 2 diabetes in the ARIC study. J Clin Endocrinol Metab. 2010;95: 5097-5104.

43. Maiti B, Kundranda MN, Spiro TP, Daw HA. The association of metabolic syndrome with triple-negative breast cancer. Breast Cancer Res Treat 2010;121: 479-483.

44. Vona-Davis L, Howard-McNatt M, Rose DP. Adiposity, type 2 diabetes and the metabolic syndrome in breast cancer. Obes Rev 2007;8: 395-408.

45. Calle EE, Thun MJ. Obesity and cancer. Oncogene 2004;23: 6365-6378.

46. Pischon T, Nothlings U, Boeing H. Obesity and cancer. Proc Nutr Soc 2008;67: 128-145.

47. Taliaferro-Smith L, Nagalingam A, Zhong D, Zhou W, Saxena NK, Sharma D. LKB1 is required for adiponectinmediated modulation of AMPK-S6K axis and inhibition of migration and invasion of breast cancer cells. Oncogene 2009;28: 2621-2633.

48. Díez JJ, Iglesias P. The role of the novel adipocyte-derived hormone adiponectin in human disease. Eur J Endocrinol 2003;148: 293-300.

49. Masaki T, Chiba S, Yasuda T, Tsubone T, Kakuma T, Shimomura I, et al. Peripheral, but not central, administration of adiponectin reduces visceral adiposity and upregulates the expression of uncoupling protein in agouti yellow (Ay/a) obese mice. Diabetes 2003;52: 2266-2273.

50. Kondo K, Shibata R, Unno K, Shimano M, Ishii M, Kito $\mathrm{T}$, et al. Impact of a single intracoronary administration of adiponectin on myocardial ischemia/reperfusion injury in a pig model. Circ Cardiovasc Interv 2010;3: 166-173. 